Prayogo, et al/Jurnal Ekonomi Syariah Teori dan Terapan Vol. 6 No. 3 Maret 2019: 411-427; PERBANDINGAN TINGKAT PENGHASILAN ANTARA LAKI-LAKI LAJANG DAN LAKI-LAKI MENIKAH PERSPEKTIF ISLAM (STUDI PADA PENDUDUK LAKI-LAKI INDONESIA BERDASARKAN DATA INDONESIAN FAMILY LIFE SURVEY TAHUN 2007 DAN 2014)

\title{
PERBANDINGAN TINGKAT PENGHASILAN ANTARA LAKI-LAKI LAJANG DAN LAKI-LAKI MENIKAH PERSPEKTIF ISLAM (STUDI PADA PENDUDUK LAKI-LAKI INDONESIA BERDASARKAN DATA INDONESIAN FAMILY LIFE SURVEY TAHUN 2007 DAN 2014)'
}

\author{
Frendi Prayogo \\ Departemen Ekonomi Syariah - Fakultas Ekonomi dan Bisnis - Universitas Airlangga \\ Email: frendi-p-10@feb.unair.ac.id \\ Noven Suprayogi \\ Departemen Ekonomi Syariah - Fakultas Ekonomi dan Bisnis - Universitas Airlangga \\ Email: noven.suprayogi@feb.unair.ac.id
}

\begin{abstract}
:
Marriage is worship that exemplified by Rasulullah PBUH. The purpose of marriage is making a happy family. However, economic barriers are commonly used to delay marriage even though God promises wealth for married people. The purpose of this study was to analyze the ratio of income levels between single men and married men in Indonesia based on the Islamic perspective. Subjects in this study were individuals in households aged 15 years or older who were individuals in the Indonesian Family Life Survey (IFLS) study of 24 provinces in Indonesia. This research is a quantitative research by using Mann-Whitney and Wilcoxon test. The sampling used is the documentation technique. The data used are taken from the IFLS-4 data in 2007 and IFLS-5 in 2014. The results showed that there was a significant difference in income level between a group of single men and a group of married men and there was a significant difference in income level between before and after marriage in the same sample.
\end{abstract}

Keywords: Single, Married, Income Level, Islamic Perspective

\section{PENDAHULUAN}

Aqidah islam yang berlandaskan enam rukun iman harus diterima secara utuh, tak boleh menerima sebagian dan menolak sebagian lainnya. Jika ada yang demikian maka keimanannya tak sempurna.

Rukun iman ketiga dan keempat yaitu iman kepada kitab dan rasul Allah mengandung konsekuensi bahwa seorang mukmin harus meyakini segala sesuatu yang tertulis dalam kitab Allah dan disampaikan Rasulullah SAW adalah kebenaran. Pembuktian keimanan kepada Al-Quran yaitu dengan melaksanakan perintah dan menjauhi larangan yang tertulis di dalamnya. Sedangkan pembuktian iman kepada Rasullullah SAW adalah mengikuti sunnahnya. Dengan berpedoman keduanya niscaya akan dicapai kebahagiaan hidup.

Dewasa ini kebahagiaan sering dikaitkan dengan cinta terutama terhadap lawan jenis. Menurut Kamus Besar Bahasa Indonesia, kata "cinta" memiliki arti rasa suka, kasih sekali, atau juga rasa keterpikatan antara satu orang dengan orang lainnya. Kecenderungan terhadap lawan jenis merupakan fitrah setiap manusia. Perasaan cinta harus

1) Jurnal ini merupakan bagian dari skripsi Frendi Prayogo, NIM: 041014023, yang diuji pada tanggal 18 Januari 2018. 
Prayogo, et al/Jurnal Ekonomi Syariah Teori dan Terapan Vol. 6 No. 3 Maret 2019: 411-427; PERBANDINGAN TINGKAT PENGHASILAN ANTARA LAKI-LAKI LAJANG DAN LAKI-LAKI MENIKAH PERSPEKTIF ISLAM (STUDI PADA PENDUDUK LAKI-LAKI INDONESIA BERDASARKAN DATA INDONESIAN FAMILY LIFE SURVEY TAHUN 2007 DAN 2014)

dikelola agar tak bertentangan dengan syariat.

Islam memberikan solusi perasaan cinta terhadap lawan jenis melalui ikatan pernikahan. Pelaksanaan pernikahan merupakan salah satu bentuk pemenuhan fitrah dengan cara yang baik dan benar berdasarkan norma agama, hukum, dan sosial.

Rasullullah SAW menganjurkan umatnya untuk menikah. Perintah menikah juga terdapat dalam Al-Qur,an Surat An-Nuur ayat 32:

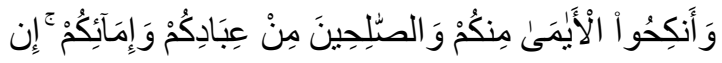

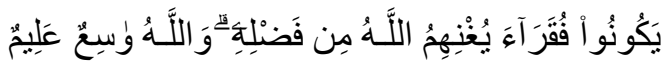

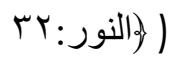

Wa-ankihuu al-ayaamaa minkum waalshshaalihiina min 'ibaadikum waimaa-ikum in yakuunue fuqaraa-a yughnihimu allaahu min fadhlihi waallaahu waasi'un 'aliimun (An Nuur:

32)

"Dan kawinkanlah orang-orang yang sedirian diantara kamu, dan orangorang yang layak (berkawin) dari hamba-hamba sahayamu yang lelaki dan hamba-hamba sahayamu yang perempuan. Jika mereka miskin Allah akan mengayakan mereka dengan karunia-Nya. Dan Allah Maha luas (pemberian-Nya) lagi Maha Mengetahui (QS: An Nuur: 32) (Departemen Agama Republik Indonesia, 1992)"

Tafsir ayat di atas menurut As-Sa'di (2007):

"Jika mereka miskin", yaitu para suami dan orang yang telah menikah "niscaya Allah akan memampukan mereka dengan karuniaNya, "sehingga janganlah menjadi penghalang apa yang kalian dugakan bahwa bila dia menikah nanti, maka akan jatuh miskin sebab banyaknya tanggungan dan lainnya. Pada ayat ini terkandung anjuran untuk menikah dan janji Allah kepada orang yang menikah dengan kecukupan setelah kondisi kefakirannya.

Meskipun sudah ada jaminan dari Allah, terdapat kecenderungan di kalangan pemuda untuk menunda bahkan mengabaikan urusan pernikahan. Salah satu alasannya adalah faktor ekonomi. Bagi wanita, keputusan melajang karena kemandirian atau independensi ekonomi. Sedang bagi lakilaki, melajang karena rasa takut akan ketidakmampuan memenuhi kebutuhan ekonomi keluarga Diana (2008).

Dari hasil penelitian Diana, menarik untuk diteliti jika penghasilan dihubungkan dengan janjiAllah bagilaki-laki yang menikah. Di sisi lain, Hill dalam Hewitt (2002) menyimpulkan bahwa orang yang menikah lebih kaya daripada orang yang lajang didasarkan pada rata-rata tingkat penghasilan.

Berdasarkan permasalahan diatas peneliti berkeinginan untuk membandingkan tingkat penghasilan antara laki-laki lajang dan laki-laki menikah berdasarkan perspektif Islam.

\section{LANDASAN TEORI}

Pernikahan atau perkawinan adalah ikatan lahir dan batin antara 
Prayogo, et al/Jurnal Ekonomi Syariah Teori dan Terapan Vol. 6 No. 3 Maret 2019: 411-427; PERBANDINGAN TINGKAT PENGHASILAN ANTARA LAKI-LAKI LAJANG DAN LAKI-LAKI MENIKAH PERSPEKTIF ISLAM (STUDI PADA PENDUDUK LAKI-LAKI INDONESIA BERDASARKAN DATA INDONESIAN FAMILY LIFE SURVEY TAHUN 2007 DAN 2014)

seorang pria dengan seorang wanita sebagai suami istri dengan tujuan membentuk keluarga (rumah tangga) yang bahagia dan kekal berdasarkan Ketuhanan Yang Maha Esa(UU No. 1 tahun 1974).

Menurut Imam al Ghozali (tanpa tahun: 22) tujuan pernikahan adalah:

1. Mendapatkan dan melangsungkan keturunan.

2. Memenuhi hajat manusia untuk menyalurkan syahwat dan menumpahkan kasih sayang.

3. Memenuhi panggilan agama, memelihara diri dari kejahatan dan kerusakan.

4. Menumbuhkan kesungguhan untuk bertanggung jawab, menerima hak serta kewajiban, dan untuk memperoleh harta kekayaan yang halal.

5. Membangun rumah tangga untuk membentuk masyarakat yang tentram atas dasar cinta dan kasih sayang.

Islam menyukai dan menganjurkan pernikahan karena di dalamnya terdapat kemaslahatan dan faedah yang dapat dirasakan oleh individu pelaku dan masyarakat (Al Blgha dkk., 2008: 601). Sayid Sabiq dalam Fiqh Sunnah (2008: 206) menjelaskan bahwa Islam menganjurkan umatnya untuk melaksanakan pernikahan dengan berbagai bentuk anjuran:

1. Menikah merupakan sunnah para nabi dan risalah para rasul. Sebagai umat kita berkewajiban meneladani mereka. Allah SWT berfirman,"Dan sungguh, Kami telah mengutus beberapa rasul sebelum engkau (Muhammad) dan Kami berikan kepada mereka istri-istri dan keturunan...." (ar-Ra'd, 13:8)

2. Anjuran menikah dalam bentuk pujian. Sebagaimana firman Allah, "Dan Allah jadikan bagimu pasangan (suami atau istri) dari jenis kamu sendiri dan menjadikan anak dan cucu bagimu dari pasanganmu, serta memberimu rezeki dari yang baik....." (an-Nahl, 16:72)

3. Menikah merupakan salah satu tanda kekuasaan Allah SWT. Allah berfirman, "Dan diantara tandatanda (kebesaran)-Nya ialah Dia menciptakan pasangan-pasangan untukmu dari jenismu sendiri, agar kamu cenderung dan merasa tentram kepadanya, dan Dia menjadikan di antaramu rasa kasih dan sayang. Sungguh, pada yang demikian itu benar-benar terdapat tanda-tanda (kebesaran Allah) bagi kaum yang berpikir." (ar-Ruum, 30:21)

4. Terkadang seseorang dihinggapi perasaan ragu lalu enggan melaksanakan pernikahan. Hal itu disebabkan oleh rasa takut jika nantinya harus mengambil alih tanggung jawab menghidupi keluarga, sehingga menjadikan dirinya terbebani. Karena itu, islam selalu menekankan bahwa Allah SWT menjadikan pernikahan sebagai sarana untuk memperoleh 
Prayogo, et al/Jurnal Ekonomi Syariah Teori dan Terapan Vol. 6 No. 3 Maret 2019: 411-427; PERBANDINGAN TINGKAT PENGHASILAN ANTARA LAKI-LAKI LAJANG DAN LAKI-LAKI MENIKAH PERSPEKTIF ISLAM (STUDI PADA PENDUDUK LAKI-LAKI INDONESIA BERDASARKAN DATA INDONESIAN FAMILY LIFE SURVEY TAHUN 2007 DAN 2014)

kekayaan, mengurangi beban kehidupan, dan memberinya kekuatan yang dapat menghindarkan manusia dari kemiskinan. Sebagaimana firman Allah SWT dalam surat an -Nuur ayat 32.

5. Perempuan merupakan asset terbaik yang dimiliki loleh seorang laki-laki. Sebagaimana hadits yang diriwayatkan oleh Muslim, hadits nomor 64: "Dunia adalah perhiasan; dan perhiasan dunia yang paling baik adalah perempuan yang salehah."

6. Kadang terbersit di dalam benak manusia untuk hidup membujang dan memutuskan hubungan dengan kehidupan duniawi. Islam mengajarkan bahwa hal seperti itu bertolak belakang dengan fitrah manusia dan bertentangan dengan agama. Rasullullah sebagai sebaikbaiknya teladan melarang hal tersebut sebagaimana hadits yang diriwayatkan oleh Bukhari, dalam kitab an-Nikah, yang artinya: "Adakah kalian berkata begitu? Demi Allah, di antara kamu sekalian, aku adalah orang yang paling takut dan bertakwa kepada Allah. Namun begitu, aku berpuasa, kemudian berbuka, shalat, kemudian tidur, dan aku menikahi perempuan. Barang siapa yang enggan mengikuti sunnahku, maka ia bukanlah pengikutku."
7. Istri salehah selalu mendatangkan kebahagiaan di dalam rumah tangga, menghiasi rumah tangga dengan keceriaan, rasa aman, serta kemuliaan. Sebagaimana hadits yang diriwayakan Ibnu Majah, hadits nomor 1857 yang artinya: "Tak ada kebahagiaan bagi seorang mukmin (suami)-setelah ketakwaannya kepada Allah SWT- yang lebih baik baginya selain seorang istri salehah, (yaitu istri yang) menaati perintah suaminya, membuat hati suaminya sejukketika ia melihatnya, berbakti ketika suaminya bersumpah, serta dapat menjaga kehormatan dirinya dan harta suaminya ketika suaminya tidak ada di sisinya."

8. Menikah merupakan salah satu bentuk ketaan muslim (ibadah) untuk menyempurnakan separuh agamanya. Dengan menikah, ia dapat menghadap Allah SWT dalam keadaan yang paling baik (suci). "Barang siapa yang ingin bertemu Allah dalam keadaan suci, maka hendaklah ia menikahi prempuan merdeka (bukan budak)." (Hadits riwayat Ibnu Majah nomor 1862)

Nikah memiliki hokum yang berbeda-beda, hukumnya bukan hanya satu. Al Bigha dkk., (2008: 602) dalam Fikih Manhaji menjelaskan bahwa hal ini mengikuti keadaan yang terdapat pada seseorang. Penjelasannya sebagai berikut.

1. Sunnah

Apabila seseorang memiliki hasrat yang mendorong untuk menikah 
Prayogo, et al/Jurnal Ekonomi Syariah Teori dan Terapan Vol. 6 No. 3 Maret 2019: 411-427; PERBANDINGAN TINGKAT PENGHASILAN ANTARA LAKI-LAKI LAJANG DAN LAKI-LAKI MENIKAH PERSPEKTIF ISLAM (STUDI PADA PENDUDUK LAKI-LAKI INDONESIA BERDASARKAN DATA INDONESIAN FAMILY LIFE SURVEY TAHUN 2007 DAN 2014)

serta memiliki bekal dan nafkah yang cukup, berupa mahar dan nafkah untuk menghidupi diri dan istrinya. Namun, tidak terdapat kekhawatiran akan terjerumus dalam perbuatan maksiat jika tidak menikah.

2. Sunnah tidak Menikah

Apabila seseorang butuh untuk menikah, tetapi ia tidak punya persiapan dan nafkah.

3. Makruh

Apabila seseorang tidak butuh menikah, seumpama tidak memiliki hasrat. Dapat juga karena sakit, cacat serta tidak memiliki persiapan untuk menikah.

4. Lebih utama meninggalkannya

Apabila seseorang memiliki persiapan untuk menikah, tetapi tidak memiliki hasrat untuk menikah. Sementara ia menyibukkan dirinya dengan ibadah atau mencari ilmu.

5. Lebih utama menikah Apabila seseorang tidak mencurahkan waktunya untuk beribadah juga mencari ilmu, sementara ia mempunyai persiapan untuk menikah, tetapi ia tidak butuh menikah.

Islam mensyari'atkan pernikahan untuk membentuk mahligai keluarga sebagai sarana untuk meraih kebahagiaan hidup. Islam juga mengajarkan pernikahan merupakan suatu peristiwa yang patut disambut dengan rasa syukur dan gembira (Atabik,
2014). Menurut Sabiq (2008: 10) terdapat beberapa hikmah pernikahan:

1. Sesungguhnya naluri seks merupakan naluri yang paling kuat dan keras yang selamanya menuntut adanya jalan keluar. Apabila jalan keluar tidak dapat memuaskannya, maka akan terjadi kegoncangan dan kekacauan yang mengakibatkan kejahatan. Pernikahan merupakan jalan yang terbaik dalam manyalurkan hasrat seksual. Dengan pernikahan tubuh menjadi lebih segar, jiwa jadi tenang, mata terpelihara dari melihat yang haram dan perasaan tenang menikmati barang yang halal.

2. Meneruskan keturunan dan memeliharan nasab, karena dengan pernikahan akan diperoleh nasab secara halal dan terhormat. Ini merupakan kebanggaan bagi individu dan keluarga bersangkutan dan ini merupakan insting manusia untuk berketurunan dan melestarikan nasabnya.

3. Meningkatkan rasa tanggung jawab, karena dengan pernikahan berarti masing-masing pihak dibebani tanggungjawab sesuai dengan fungsi masing-masing. Suami sebagai kepala rumahtangga bertanggungjawab atas nafkah keluarganya, sedangkan istri bertanggungjawab atas pemeliharaan anak dan 
Prayogo, et al/Jurnal Ekonomi Syariah Teori dan Terapan Vol. 6 No. 3 Maret 2019: 411-427; PERBANDINGAN TINGKAT PENGHASILAN ANTARA LAKI-LAKI LAJANG DAN LAKI-LAKI MENIKAH PERSPEKTIF ISLAM (STUDI PADA PENDUDUK LAKI-LAKI INDONESIA BERDASARKAN DATA INDONESIAN FAMILY LIFE SURVEY TAHUN 2007 DAN 2014)

pengkondisian rumah tangga menjadi lebih nyaman dan tentram.

4. Membuahkan tali kekeluargaan, memperteguh kelanggengan rasa cinta antar keluarga dan memperkuat hubungan kemasyarakatan, masyarakat yang saling mencintai dan saling menunjang merupakan masyarakat yang kuat dan bahagia.

Sedangkan pengertian lajang menurut Kamus Besar Bahasa Indonesia, kata "lajang" berarti sendirian, bujangan atau belum menikah, sehingga lajang berarti orang dewasa yang belum menikah. Stein dalam Septiana (2013) mendefinisikan lajang sebagai orang yang cukup usia tetapi belum atau tidak menikah.

Islam melarang seseorang sengaja melajang meskipun tujuannya adalah untuk beribadah kepada Allah (tabattul). Rasullullah SAW membenci hal ini dan tidak mengakui orang yang berbuat demikian sebagai golongannya, sebagaimana hadits yang diriwayatkan Imam Muslim (tanpa tahun: 1020):

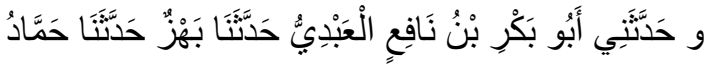

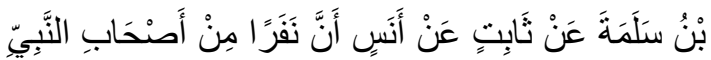

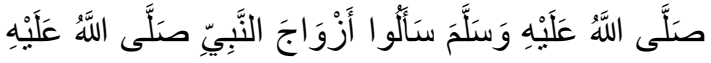

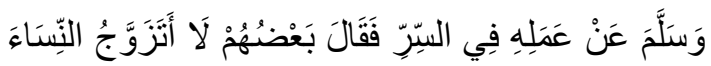

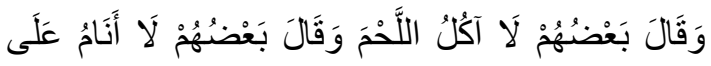

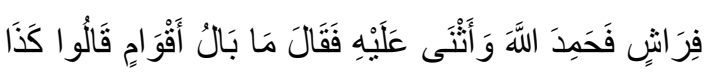

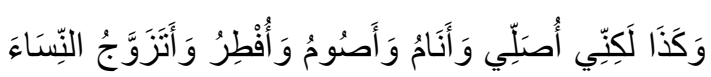

فَمَنْ رَغِبَ عَنْ سُنَّنِي فَلَيْنَ مِنِّي. (رواه مسلم :

$(Y \leq \Lambda V$

Wa khadatstsanii abuu bakribnu naafi'il 'abdiyyu khadatstsanaa bahrun khadatstsanaa khammadubnu salamatan 'an tsaabitin 'an anasin anna nafron min ashkhaabinnabiyyi sholallohu 'alaihi wasallama 'an 'amalihi fissirri faqoola ba'dhuhum laa atazawwaju annisaa a wa qoola ba'dhuhum laa akullullakhma wa qoola ba'dhuhum laa anaamu 'alaa firoosyin fakhamidallooha wa atsnaa 'alaihi fa qoola maa baalu aqwaamin qooluu kadzaa wa kadzaa lakinnii ushollii wa anaamu wa ashuumu wa afthiru wa atazawwaju annnisaa a faman roghiba 'an sunnatii falaisa minnii. (Rowahu muslim: 2487)

"Dan telah menceritakan kepadaku Abu Bakar bin Nafi' Al Abdi, telah menceritakan kepada kami Bahz, telah menceritakan kepada kami Hammad bin Salama, dari Tsabit, dari Anas bahwa sekelompok orang dari kalangan sahabat Nabi saw bertanya kepada isteri-isteri Nabi saw mengenai amalan beliau yang tersembunyi. Maka sebagian dari mereka pun berkata : 'Saya tidak akan menikah.' Kemudian sebagian lagi berkata: 'Aku tidak akan makan daging.' Dan sebagian lain lagi berkata: 'Aku tidak akan tidur di atas kasurku.' Mendengar ucapan-ucapan itu, Nabi saw memuji Allah dan menyanjung-Nya, kemudian beliau 
Prayogo, et al/Jurnal Ekonomi Syariah Teori dan Terapan Vol. 6 No. 3 Maret 2019: 411-427; PERBANDINGAN TINGKAT PENGHASILAN ANTARA LAKI-LAKI LAJANG DAN LAKI-LAKI MENIKAH PERSPEKTIF ISLAM (STUDI PADA PENDUDUK LAKI-LAKI INDONESIA BERDASARKAN DATA INDONESIAN FAMILY LIFE SURVEY TAHUN 2007 DAN 2014)

bersabda: "Ada apa dengan mereka? Mereka berkata begini dan begitu, padahal aku sendiri shalat dan juga tidur, berpuasa dan juga berbuka, dan aku juga menikahi wanita. Maka siapa saja yang membenci sunnahku, berarti bukan dari golonganku." (HR.Muslim: 2487)

Salah satu faedah menikah adalah meningkatkan kekayaan. Dalam hal ini penghasilan digunakan sebagai indikator tingkat kekayaan. Menurut IAI dalam Kuheba (2016: 82) penghasilan didefinisikan sebagai penigkatan manfaat ekonomi selama priode akuntansi dalam bentuk arus masuk atau penigkatan asset atau penurunan liabilitas yang mengakibatkan kenaikan ekuitas, yang tidak berasal dari kontribusi penanaman modal. Penghasilan (income) meliputi pendapatan (revenue) maupun keuntungan (gain).

Menurut Standar Akuntansi Keuangan (2007:13) sebagaimana tertulis dalam kerangka dasar penyusunan dan penyajian laporan kevangan, penghasilan adalah "Kenaikan manfaat ekonomi selama suatu periode akuntansi tertentu dalam bentuk pemasukkan atau penambahan aset atau penurunan kewajiban yang mengakibatkan kenaikan ekuitas yang tidak berasal dari kontribusi penanaman modal".

Berdasarkan penelitian terdahulu (Hill, 1979) disimpulkan bahwa penghasilan laki-laki menikah lebih tinggi daripada penghasilan laki-laki lajang.
Terdapat dua alasan yang dapat menjelaskan hal ini.:

1. Efek Spesialisasi

Penelitian Becker dalam Dalmia (2016) menyimpulkan bahwa pernikahan membuat laki-laki lebih produktif yang disebabkan adanya spesialisasi kerja dalam rumah tangga. Spesialisasi ini membuat laki-laki lebih bisa memusatkan perhatiannya dalam bekerja dan perhatiannya dalam meningkatkan kapasitas sumber daya manusia (SDM). Kedua hal ini pada gilirannya bisa meningkatkan penghasilan laki-laki. Di sisi lain, biaya hidup bersama menjadi lebih murah dibandingkan hidup terpisah. Becker juga menyimpulkan bahwa setelah menikah muncul rasa tanggung jawab yang lebih kuat dalam diri laki-laki karena ia tidak hanya bertanggung jawab pada kesejahteraan dirinya tetapi juga istri dan keluarganya.

2. Efek Produktivitas Silang (CrossProductivity)

Benham dalam Dalmia (2016) berpendapat bahwa istri yang berpendidikan akan meningkatkan produktivitas suami. Istri berperan sebagai rekan suami dalam banyak hal. la bisa memberikan saran, dukungan emosional, memotivasi dan memberikan solusi terkait masalah pekerjaan suami. Istri yang berpendidikan juga bisa membantu suami dalam meningkatkan keterampilannya sehingga meningkatkan penghasilan. 
Prayogo, et al/Jurnal Ekonomi Syariah Teori dan Terapan Vol. 6 No. 3 Maret 2019: 411-427; PERBANDINGAN TINGKAT PENGHASILAN ANTARA LAKI-LAKI LAJANG DAN LAKI-LAKI MENIKAH PERSPEKTIF ISLAM (STUDI PADA PENDUDUK LAKI-LAKI INDONESIA BERDASARKAN DATA INDONESIAN FAMILY LIFE SURVEY TAHUN 2007 DAN 2014)

Memperoleh kekayaan dengan cara menikah merupakan janji Allah SWT. Terdapat beberapa dalil berupa ayat Al-Quran dan hadits berkaitan dengan hal ini:

1. Al-Quran Surah An-Nuur ayat 32:

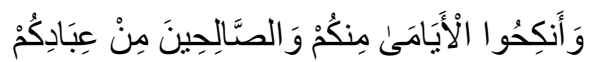

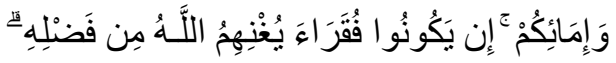

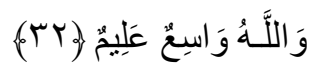

Wa-ankihuu al-ayaamaa minkum waalshshaalihiina min 'ibaadikum waimaa-ikum in yakuunue fuqaraa-a yughnihimu allaahu min fadhlihi waallaahu waasi'un 'aliimun

Artinya: "Dan kawinkanlah orangorang yang sedirian diantara kamu, dan orang-orang yang layak (berkawin) dari hamba-hamba sahayamu yang lelaki dan hambahamba sahayamu yang perempuan. Jika mereka miskin Allah akan mengayakan mereka dengan karuniaNya. Dan Allah Maha luas (pemberianNya) lagi Maha Mengetahui." (QS. An Nuur: 32) (Departemen Agama Republik Indonesia, 1992)

Berkaitan dengan ayat tersebut Umar bin Khattab RA berkomentar sebagai berikut (Sasmita, 2012: 72).

"Aku heran dengan orang yang tidak mau mencari kekayaan dengan cara menikah. Padahal Allah berfirman: Jika mereka miskin, maka Allah akan membuat mereka kaya dengan Keutamaan-Nya" .

2. Al-Quran Surah Al-Israa ayat 31:

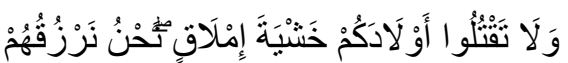

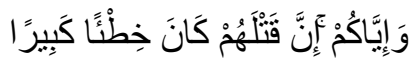

Walaa taqtuluu awlaadakum khasyyata imlaaqin nahnu narzuquhum wa-iyyaakum inna qatlahum kaana khith-an kabiiraan

Artinya: "Dan janganlah kamu membunuh anak-anakmu karena takut kemiskinan. Kamilah yang akan memberi rezki kepada mereka dan juga kepadamu. Sesungguhnya membunuh mereka adalah suatu dosa yang besar." (QS. Al-Israa: 31) (Departemen Agama Republik Indonesia, 1992)

Berdasarkan janji Allah SWT tersebut, seorang muslim tak boleh khawatir dengan rezeki anak-anaknya apalagi sampai berpikir untuk membunuh karena kesulitan secara ekonomi. Karena Allah lah yang akan memberikan rezeki kepada mereka. Hal ini merupakan jaminan langsung dari Allah SWT berkaitan dengan rezeki anak dan kedua orang tuanya.

3. Hadits Riwayat An-Nasa'i nomor 3218:

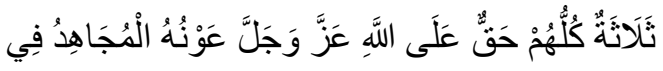

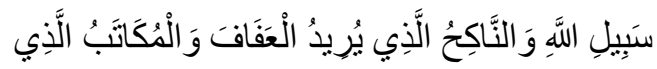

$$
\begin{aligned}
& \text { يُرِيدُ الَْذَدَاءَ }
\end{aligned}
$$

Tsalaatsatun kulluhum khaqqun 'alaihi 'azza wajalla 'aunuhu almujaahidu fii sabiilillaahi wannaakikhu alladzi yuriidu al 'afaafa wal mukaatabu alladzii yuriidu al adaa a

Artinya: "Ada tiga orang yang akan mendapatkan pertolongan Allah: (1) 
Prayogo, et al/Jurnal Ekonomi Syariah Teori dan Terapan Vol. 6 No. 3 Maret 2019: 411-427; PERBANDINGAN TINGKAT PENGHASILAN ANTARA LAKI-LAKI LAJANG DAN LAKI-LAKI MENIKAH PERSPEKTIF ISLAM (STUDI PADA PENDUDUK LAKI-LAKI INDONESIA BERDASARKAN DATA INDONESIAN FAMILY LIFE SURVEY TAHUN 2007 DAN 2014)

orang yang berjihad di jalan Allah, (2) orang yang menikah demi menjaga kesucian dirinya, (3) budak mukatab yang ingin membebaskan dirinya." (HR. An-Nasa'i: 3218) (An Nasa'i, tanpa tahun)

Dari hadis di atas, seorang mukmin harus yakin bahwa Allah SWT pasti memberi pertolongan bagi orang yang menikah demi menjaga kesucian dirinya.

4. Hadits Riwayat Muslim nomor 1010:

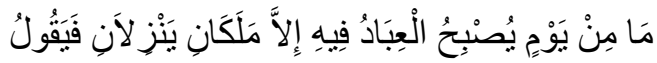

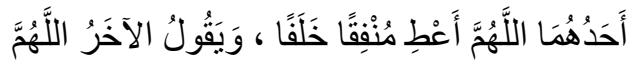
أَعْطِ مُمْسِكًا تَلَفًا

Maa min yaumin yashbikhu al'ibaadu fiihi ilaa malakaani yanzilaani fayaquulu akhaduhumaa allohumma a'thi munfiqon kholafan wa yaquulu al akhoru allohumma a'thi mumsikan talafan

Artinya: "Ketika hamba berada di setiap pagi, ada dua malaikat yang turun dan berdoa, "Ya Allah berikanlah ganti pada yang gemar berinfak (rajin memberi nafkah pada kelvarga)." Malaikat yang lain berdoa, "Ya Allah, berikanlah kebangkrutan bagi yang enggan bersedekah (memberi nafkah)." (HR. Muslim: 1010) (Muslim, tanpa tahun)

Imam Nawawi (7: 187) menjelaskan hadits doa di atas, "Para ulama menyatakan bahwa infak yang dimaksud adalah infak dalam ketaatan, infak untuk menunjukkan akhlak yang mulia, infak pada kelvarga, infak pada orang-orang yang lemah, serta lainnya. Selama infak tersebut tidaklah berlebihan, alias boros."

Berdasarkan hadits di atas, orang yang memberi nafkah pada keluarga, kerabat, dan rajin mengeluarkan sedekah sunnah maka malaikat mendoakan agar orang tersebut mendapatkan ganti.

Adapun hipotesis dari penelitian ini yaitu.

\section{Hipotesis Pertama}

(Ho): $\mu 1=\mu 2: \quad$ Tida

ada perbedaan tingkat penghasilan antara kelompok laki-laki lajang dan kelompok laki-laki menikah pada tahun 2007

$(\mathrm{H} 1): \mu 1 \neq \mu 2: \quad$ Ada $\quad$ perbedaan tingkat penghasilan antara kelompok laki-laki lajang dan kelompok laki-laki menikah pada tahun 2007

2. Hipotesis Kedua

$(\mathrm{Ho}): \mu 1=\mu 2: \quad$ Tidak ada perbedaan tingkat penghasilan antara kelompok laki-laki lajang dan kelompok laki-laki menikah pada tahun 2014

$(\mathrm{H} 1): \mu 1 \neq \mu 2: \quad$ Ada perbedaan tingkat penghasilan antara kelompok laki-laki lajang dan kelompok laki-laki menikah pada tahun 2014

3. Hipotesis Ketiga

$(\mathrm{Ho}): \mu 1=\mu$ : Tidak ada perbedaan tingkat 
Prayogo, et al/Jurnal Ekonomi Syariah Teori dan Terapan Vol. 6 No. 3 Maret 2019: 411-427; PERBANDINGAN TINGKAT PENGHASILAN ANTARA LAKI-LAKI LAJANG DAN LAKI-LAKI MENIKAH PERSPEKTIF ISLAM (STUDI PADA PENDUDUK LAKI-LAKI INDONESIA BERDASARKAN DATA INDONESIAN FAMILY LIFE SURVEY TAHUN 2007 DAN 2014)

penghasilan antara individu laki-laki sebelum dan setelah menikah

$(H 1): \mu 1 \neq \mu 2: \quad$ Ada perbedaan tingkat penghasilan antara individu laki-laki sebelum dan setelah menikah

\section{METODE PENELITIAN}

Uji Normalitas: suatu pengujian yang dilakukan untuk mengetahui normal atau tidaknya distribusi data. Pengujian ini digunakan untuk menentukan alat analisis yang tepat. Uji Normalitas pada penelitian ini menggunakan uji Kolmogorov-Smirnov.

Uji Mann-Whitney: uji nonparametrik yang digunakan untuk mengetahui perbedaan median dua kelompok bebas apabila skala data variabel terikatnya adalah ordinal atau interval/ratio tetapi tidak berdistribusi normal. Secara garis besar pada uji MannWhitney diperoleh dua sampel random yang ukurannya bisa berbeda dan bisa sama.

Uji Wilcoxon : uji non-parametrik menganalisis hasil-hasil pengamatan yang berpasangan dari dua data apakah berbeda atau tidak. Uji Wilcoxon ini digunakan hanya untuk data bertipe interval atau ratio, namun datanya tidak mengikuti distribusi normal.

Data yang digunakan dalam penelitian ini adalah data sekunder yang diperoleh dari lembaga survei yaitu Indonesia Family Life Survey. Dalam penelitian ini, peneliti menggunakan data IFLS-4 tahun 2007 dan IFLS-5 tahun 2014.Subjek dalam penelitian ini adalah individu dalam rumah tangga yang berusia 15 tahun atau lebih yang merupakan individu dalam penelitian Indonesia Family Life Survey (IFLS) dalam 24 provinsi di Indonesia.

Dalam penelitian ini terdapat satu variabel yang digunakan, yaitu penghasilan per tahun.

\section{HASIL DAN PEMBAHASAN}

Sebelum dilakukan uji MannWhitney dan uji Wilcoxon, terlebih dahulu dilakukan uji Kolmogorov-Smirnov. Hasilnya diketahui bahwa seluruh hasil pengujian (Asymp.Sig) memiliki nilai yang sama yaitu 0,000 . Karena semua sampel memiliki nilai signifikansi di bawah 0,05 maka seluruh variabel tidak berdistribusi normal. Berdasarkan hasil uji normalitas di atas maka uji Mann-Whitney dan uji Wilcoxon merupakan alat uji beda yang tepat.

Tabel 1.

\section{Hasil Uji Mann-Whitney Data Tahun 2007}

\begin{tabular}{|c|c|}
\hline Test Statistics & Penghasilan \\
\hline Mann-Whitney U & 39054,500 \\
\hline Z & $-7,875$ \\
\hline $\begin{array}{c}\text { Asymp. Sig. (2- } \\
\text { tailed) }\end{array}$ &, 000 \\
\hline
\end{tabular}

Sumber : Data Olahan Penelitian

Berdasarkan Tabel 1 terlihat bahwa nilai Asymp. Sig. lebih kecil dari 0.05 yaitu 0,00 maka $\mathrm{Hl}$ diterima dan $\mathrm{HO}$ ditolak. Hal ini berarti hipotesis yang menyatakan bahwa tidak ada perbedaan tingkat penghasilan antara kelompok laki-laki lajang dan kelompok kelompok laki-laki menikah ditolak, artinya terdapat perbedaan tingkat penghasilan pada dua kelompok tersebut dimana penghasilan 
Prayogo, et al/Jurnal Ekonomi Syariah Teori dan Terapan Vol. 6 No. 3 Maret 2019: 411-427; PERBANDINGAN TINGKAT PENGHASILAN ANTARA LAKI-LAKI LAJANG DAN LAKI-LAKI MENIKAH PERSPEKTIF ISLAM (STUDI PADA PENDUDUK LAKI-LAKI INDONESIA BERDASARKAN DATA INDONESIAN FAMILY LIFE SURVEY TAHUN 2007 DAN 2014)

kelompok laki-laki menikah 2007 lebih tinggi daripada penghasilan kelompok laki-laki lajang 2007.

Tabel 2.

\section{Hasil Uji Mann-Whitney Data Tahun 2014}

\begin{tabular}{|l|l|}
\hline Test Statistics & Penghasilan \\
\hline Mann-Whitney U & 17387493,500 \\
\hline$Z$ & $-6,137$ \\
\hline $\begin{array}{l}\text { Asymp. Sig. (2- } \\
\text { tailed) }\end{array}$ &, 000 \\
\hline
\end{tabular}

Sumber : Data OlahanPenelitian

Sementara itu berdasarkan Tabel 2 signifikansi lebih kecil dari 0.05 yaitu 0,00. Kesimpulan dari uji beda ini adalah sama dengan tabel 1 di atas, yaitu terdapat perbedaan tingkat penghasilan dimana penghasilan kelompok laki-laki menikah 2014 lebih tinggi daripada penghasilan kelompok laki-laki lajang 2014. Hasil Uji beda menerima $\mathrm{Hl}$ dan menolak $\mathrm{HO}$.

Tabel 3.

Hasil UjiStatistik Wilcoxon

\begin{tabular}{|c|c|}
\hline & $\begin{array}{c}\text { Setelah Nikah - } \\
\text { Sebelum Nikah }\end{array}$ \\
\hline Z & $-5,463^{\mathrm{b}}$ \\
\hline $\begin{array}{c}\text { Asymp. Sig. (2- } \\
\text { tailed) }\end{array}$ &, 000 \\
\hline
\end{tabular}

Sumber : Data Olahan Penelitian

Berdasarkan hasil pengujian Pada

Tabel 3 di atas menunjukkan bahwa nilai Asymp. Sig. yaitu 0,00 lebih kecil daripada tingkat signifikansi yang telah ditetapkan (0.05). Dengan demikian dapat disimpulkan bahwa $\mathrm{HO}$ ditolak dan $\mathrm{HI}$ diterima. Artinya terdapat perbedaan yang signifikan antara penghasilan individu laki-laki sebelum dan sesudah menikah.

Hasil penelitian menunjukkan bahwa penghasilan kelompok laki-laki menikah lebih tinggi daripada dengan penghasilan kelompok laki-laki lajang. Hal ini bisa dilihat dari nilai rata-rata penghasilan kelompok laki-laki menikah yang lebih tinggi daripada penghasilan kelompok laki-laki lajang pada dua tahun pengujian. Pada pengujian tahun 2007 rata-rata penghasilan kelompok laki-laki menikah $\mathrm{Rp}$ 6.939.710,- sedangkan ratarata penghasilan kelompok lajang $\mathrm{Rp}$ 2.525.835,--. Sementara itu pada pengujian tahun 2014 rata-rata penghasilan kelompok laki-laki menikah Rp 21.901.509,sedangkan rata-rata penghasilan kelompok lajang $\operatorname{Rp} 18.672 .310,-$.

$\mathrm{Di}$ sisi lain berdasarkan pengamatan pada individu, penghasilan laki-laki setelah menikah lebih tinggi dibandingkan dengan penghasilan lakilaki sebelum menikah. Hal ini bisa dilihat dari nilai rata-rata penghasilan laki-laki setelah menikah yang lebih tinggi daripada penghasilan laki-laki sebelum menikah. Individu laki-laki setelah menikah memiliki rata-rata penghasilan $\mathrm{Rp}$ 21.667.391,- sedangkan individu laki-laki sebelum menikah memiliki rata-rata penghasilan $\operatorname{Rp} 6.138 .043,-$.

Jika dilihat berdasarkan karakteristik perubahan status pernikahan, penghasilan laki-laki setelah menikah semuanya mengalami kenaikan. Hal ini dapat dilihat dari perbandingan penghasilan minimum individu laki-laki 
Prayogo, et al/Jurnal Ekonomi Syariah Teori dan Terapan Vol. 6 No. 3 Maret 2019: 411-427; PERBANDINGAN TINGKAT PENGHASILAN ANTARA LAKI-LAKI LAJANG DAN LAKI-LAKI MENIKAH PERSPEKTIF ISLAM (STUDI PADA PENDUDUK LAKI-LAKI INDONESIA BERDASARKAN DATA INDONESIAN FAMILY LIFE SURVEY TAHUN 2007 DAN 2014)

sebelum dan setelah menikah. Penghasilan minimum sebelum menikah adalah $\mathrm{Rp}$ 0,- sedangkan penghasilan minimum setelah menikah menikah $\mathrm{Rp}$ 210.000,-.

Sementara itu, berdasarkan karakteristik jumlah jam kerja dalam seminggu laki-laki lajang memiliki kecenderungan jumlah jam kerja yang rendah. Hal ini tampak dari prosentase laki-laki lajang dengan jumlah jam kerja kurang dari 15 jam yang memiliki prosentase terbesar. Pada pengamatan tahun 2007 prosentasenya 60,89\%, sedangkan pada tahun 2014 prosentasenya $27,92 \%$. Prosentase keduanya merupakan yang terbesar pada masng-masing pengamatan. Sementara itu laki-laki menikah yang bekerja kurang dari 15 jam seminggu memiliki prosentase yang rendah. Pada pengamatan 2007 prosentase 16,01\% sedangkan pada 2014 prosentasenya $2,08 \%$. Hasil yang tak jauh berbeda juga ditemui pada pengamatan data berpasangan. Mayoritas laki-laki sebelum menikah jam kerjanya kurang dari 15 jam dalam seminggu dengan prosentase sebesar $34,78 \%$. Tetapi setelah menikah prosentase ini turun menjadi $2,17 \%$. Rendahnya jam kerja laki-laki sebelum menikah juga bisa dilihat dari jenis pekerjaan. Sebelum menikah terdapat tujuh laki-laki tidak bekerja dengan prosentase $15 \%$ dari total 46 sampel. Namun setelah menikah semua laki-laki bekerja. Berdasarkan pengamatan ini dapat diambil kesimpulan jam kerja laki- laki menikah relatif lebih banyak daripada laki-laki lajang.

Keterkaitan antara jam kerja dan penghasilan dapat dijelaskan sebagai berikut. Menurut Becker dalam Dalmia (2016) rasa tanggung jawab laki-laki meningkat setelah menikah karena ia tidak hanya bertanggung jawab pada kesejahteraan dirinya sendiri tetapi juga istri dan keluarganya. Konsekuensinya ia akan meningkatkan upaya kerja (work effort) untuk memenuhi kebutuhan keluarganya. Salah satu indikator meningkat atau tidaknya upaya kerja dapat diukur berdasarkan jumlah jam kerja. Indikator ini digunakan Ahituv dalam penelitiannya (2007). Menurutnya peningkatan jam kerja dapat meningkatkan pengalaman kerja sehingga bisa meningkatkan penghasilan di masa mendatang. Kesimpulan ini tak jauh berbeda dengan pendapat Imam al Ghozali yang menyatakan salah satu tujuan pernikahan berkaitan dengan tanggung jawab dan kekayaan. Menurut Imam al Ghozali (tanpa tahun: 22) tujuan pernikahan adalah:

1. Mendapatkan dan melangsungkan keturunan.

2. Memenuhi hajat manusia untuk menyalurkan syahwat dan menumpahkan kasih sayang.

3. Memenuhi panggilan agama, memelihara diri dari kejahatan dan kerusakan.

4. Menumbuhkan kesungguhan untuk bertanggung jawab, menerima hak serta kewajiban, 
Prayogo, et al/Jurnal Ekonomi Syariah Teori dan Terapan Vol. 6 No. 3 Maret 2019: 411-427; PERBANDINGAN TINGKAT PENGHASILAN ANTARA LAKI-LAKI LAJANG DAN LAKI-LAKI MENIKAH PERSPEKTIF ISLAM (STUDI PADA PENDUDUK LAKI-LAKI INDONESIA BERDASARKAN DATA INDONESIAN FAMILY LIFE SURVEY TAHUN 2007 DAN 2014)

dan untuk memperoleh harta kekayaan yang halal.

5. Membangun rumah tangga untuk membentuk masyarakat yang tentram atas dasar cinta dan kasih sayang.

Berdasarkan hasil perbandingan ini terbukti bahwa laki-laki yang menikah memiliki penghasilan yang lebih tinggi daripada laki-laki lajang. Baik perbandingan data kelompok besar maupun perbandingan data berpasanga (sebelum-sesudah) membuktikan bahwa laki-laki menikah memiliki penghasilan lebih tinggi daripada laki-laki lajang. Hal ini sesuai janji Allah SWT dalam Al Quran Surah An-Nuur ayat 32 bahwa Dia memberikan kekayaan bagi yang menikah:

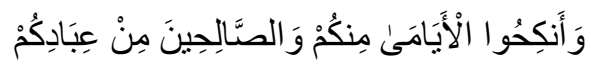

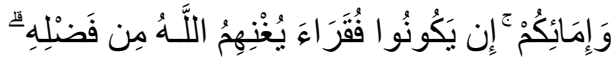

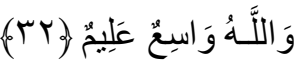

Wa-ankihuu al-ayaamaa minkum waalshshaalihiina min 'ibaadikum waimaa-ikum in yakuunue fuqaraa-a yughnihimu allaahu min fadhlihi waallaahu waasi'un 'aliimun

Artinya: "Dan kawinkanlah orangorang yang sedirian diantara kamu, dan orang-orang yang layak (berkawin) dari hamba-hamba sahayamu yang lelaki dan hamba-hamba sahayamu yang perempuan. Jika mereka miskin Allah akan mengayakan mereka dengan karunia-Nya. Dan Allah Maha luas (pemberian-Nya) lagi Maha Mengetahui."
(QS. An Nuur: 32) (Departemen Agama Republik Indonesia, 1992)

Berdasarkan pendapat ulama salah satu alasan bertambahnya kekayaan bagi laki-laki yang menikah disebabkan mereka menginfakkan hartanya kepada keluarganya. Pendapat ini didasarkan pada hadits berikut.

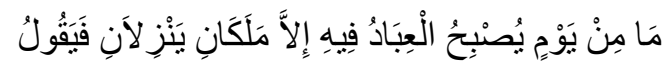

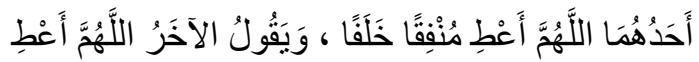
مُمْسِكًا تَكًَا

Maa min yaumin yashbikhu al'ibaadu fiihi ilaa malakaani yanzilaani fayaquulu akhaduhumaa allohumma a'thi munfiqon kholafan wa yaquulu al akhoru allohumma a'thi mumsikan talafan

Artinya: "Ketika hamba berada di setiap pagi, ada dua malaikat yang turun dan berdoa, "Ya Allah berikanlah ganti pada yang gemar berinfak (rajin memberi nafkah pada kelvarga)." Malaikat yang lain berdoa, "Ya Allah, berikanlah kebangkrutan bagi yang enggan bersedekah (memberi nafkah)." (HR. Muslim: 1010) (Muslim, tanpa tahun).

Imam Nawawi (7:

menjelaskan hadits doa di atas, "Para ulama menyatakan bahwa infak yang dimaksud adalah infak dalam ketaatan, infak untuk menunjukkan akhlak yang mulia, infak pada keluarga, infak pada orang-orang yang lemah, serta lainnya. Selama infak tersebut tidaklah berlebihan, alias boros."

\section{SIMPULAN \\ Setelah} membandingkan penghasilan laki-laki lajang dan laki-laki 
Prayogo, et al/Jurnal Ekonomi Syariah Teori dan Terapan Vol. 6 No. 3 Maret 2019: 411-427; PERBANDINGAN TINGKAT PENGHASILAN ANTARA LAKI-LAKI LAJANG DAN LAKI-LAKI MENIKAH PERSPEKTIF ISLAM (STUDI PADA PENDUDUK LAKI-LAKI INDONESIA BERDASARKAN DATA INDONESIAN FAMILY LIFE SURVEY TAHUN 2007 DAN 2014)

menikah baik secara kelompok maupun secara individu, penelitian ini menghasilkan temuan sebagai berikut.

1. Terdapat perbedaan tingkat penghasilan antara kelompok lakilaki lajang dengan kelompok lakilaki menikah tahun 2007 menurut Uji Mann-Whitney. Kelompok lakilaki menikah memiliki penghasilan yang lebih besar daripada kelompok laki-laki lajang. Rata-rata penghasilan kelompok laki-laki menikah tahun 2007 yaitu Rp 6.939.710,- sedangkan rata-rata penghasilan kelompok laki-laki lajang tahun 2007 yaitu $\mathrm{Rp}$ 2.525.835,--.

2. Terdapat perbedaan tingkat penghasilan antara kelompok lakilaki lajang dengan kelompok lakilaki menikah tahun 2014 menurut Uji Mann-Whitney. Kelompok lakilaki menikah memiliki penghasilan yang lebih besar daripada kelompok laki-laki lajang. Rata-rata penghasilan kelompok laki-laki menikah tahun 2014 yaitu Rp 21.901.509,- sedangkan rata-rata penghasilan kelompok laki-laki lajang tahun 2007 yaitu $\mathrm{Rp}$ 18.672.310,--.

3. Terdapat perbedaan tingkat penghasilan antara laki-laki sebelum menikah dan laki-laki setelah menikah pada individu yang sama menurut Uji Wilcoxon. Laki-laki setelah menikah memiliki penghasilan yang lebih besar daripada sebelum menikah. Ratarata penghasilan individu laki-laki setelah menikah yaitu $\mathrm{Rp}$ 21.667.391,- sedangkan rata-rata penghasilan individu laki-laki sebelum menikah yaitu Rp 6.138.043,-

\section{DAFTAR PUSTAKA}

Abdurahman. 1992. Kompilasi Hukum Islam di Indonesia. Jakarta: Akademika Pressindo

Abul Hasan, Muslim. Tanpa Tahun. Shahih Muslim II. Semarang: Toha Putra

Ahituv, Avner dan Robert I Lerman. 2007. How Do Marital Status, Work Effort, And Wage Rates Interact? Demography, 44 (3): s623-647

Al Bigha, Mushthafa. 2008. Fikih Manhaji. Terjemahan oleh Misran. 2012. Yogyakarta. Darul Uswah

Atabik, Ahmad dan Khoridatul Mudhilah. 2014. Pernikahan dan Hikmahnya Perspektif Islam. Yudisia, 5 (2): 286316

Dalmia, Sonia, dkk. 2016. Marriage and Men's Earnings: Specialization and Cross-Productivity Effects. Eastern Economic Journal. (42): 335-348

Departemen Agama Republik Indonesia. 2007. Mushaf Al Qur'an Terjemah. Jakarta: Tim Penerbitan Gema Insani Al Huda

Diana, Rachmy. 2008. Penundaan Pernikahan: Perspektif Islam dan Psikologi. Jurnal Psikologi, 1 (2): 163182

Dunga, Steven Henry. 2017. A Gender and Marital Status Analysis of Household 
Prayogo, et al/Jurnal Ekonomi Syariah Teori dan Terapan Vol. 6 No. 3 Maret 2019: 411-427; PERBANDINGAN TINGKAT PENGHASILAN ANTARA LAKI-LAKI LAJANG DAN LAKI-LAKI MENIKAH PERSPEKTIF ISLAM (STUDI PADA PENDUDUK LAKI-LAKI INDONESIA BERDASARKAN DATA INDONESIAN FAMILY LIFE SURVEY TAHUN 2007 DAN 2014)

Income in A Low-Income Township. Studia Universitatis Babes-Bolyai Oeconomica, 62 (1): 20-30

Furqon. 1999. Statistika Terapan untuk Penelitian. Bandung: Alfabeta.

Ghazaly, Hamid. Tanpa Tahun. Ihya' Ulumuddin. Terjemahan oleh Ismail Yakub. 1971. Beirut : Dar al Fikr

Hewitt, Belinda, dkk. 2002. Marriage and Money: The Impact of Marriage on Men's and Women's Earnings. Makalah dipresentasikan pada Australian Sociological Conference, Brisbane.

Hewitt, Belinda, dkk. 2002. Marriage and Money: The Impact of Marriage on Men's and Women's Earnings. Makalah disajikan dalam Australian Sociological Conference. Brisbane.

Ikatan Akuntan Indonesia. 2009. Kerangka Dasar Penyusunan dan Penyajian Laporan Kevangan. Jakarta: Salemba Empat

2009. Standar Akuntansi Keuangan (SAK) Tahun 2009. Jakarta: Salemba Empat

Indriantoro, Nur dan Bambang Supomo. 2002. Metodologi Penelitian Bisnis. Yogyakarta: Penerbit BPFE Yogyakarta

Ismatulloh, A. M.. 2015. Konsep Sakinah, Mawaddah, dan Rahmah dalam Al Qur'an (Perspektif Penafsiran Kitab Al Qur'an dan Tafsirnya). Jurnal Mazahib, (Online), Jilid XIV, No. 1, (https://media.neliti.com, diakses 19 Agustus 2017).
Iswati, Sri dan Muslich Anshori. 2009. Buku Ajar Metodologi Penelitian Kuantitaif. Surabaya: Airlangga University Press

Kamal, Muchtar. 2004. Asas-asas Hukum Islam Tentang Perkawinan. Jakarta: Bulan Bintang

KBBI, 2017. Kamus Besar Bahasa Indonesia (KBBI), (Online), (http://kbbi.web.id/pusat, diakses 21 Agustus 2017).

Kuheba, Jefier Andrew, dkk. 2016. Perbandingan Penghasilan Usaha Tani Campuran Berdasarkan Pengelompokan Jenis Tanaman. Agri-Sosioekonomi Unsrat, 12 (2A): $77-90$

Kuheba, Jefier Andrew. 2016. Perbandingan Pendapatan Usahatani Campuran Berdasarkan Pengelompokan Jenis Tanaman. Jurnal Agri-Sosiologi Unsrat, 12 (2A): 77-99

Kurniawati, Novi. 2012. Pernikahan Usia Dini dan Posisi Perempuan dalam Keluarga. Skripsi Tidak Diterbitkan. Bandung Universitas Islam Bandung Loughran, David $S$ dan Julie $M$. Zissimopoulos. 2004. Are There Gains to Delaying Marriage? The Effect of Age at First Marriage on Career Development and Wages. Makalah merupakan bagian dari riset RAND Labor and Population working paper series, November 8 , Santa Monica. 
Prayogo, et al/Jurnal Ekonomi Syariah Teori dan Terapan Vol. 6 No. 3 Maret 2019: 411-427; PERBANDINGAN TINGKAT PENGHASILAN ANTARA LAKI-LAKI LAJANG DAN LAKI-LAKI MENIKAH PERSPEKTIF ISLAM (STUDI PADA PENDUDUK LAKI-LAKI INDONESIA BERDASARKAN DATA INDONESIAN FAMILY LIFE SURVEY TAHUN 2007 DAN 2014)

Mahalli, A. Mudjab. 2003. Menikahlah, Engkau Menjadi Kaya. Cetakan Ketiga. Yogyakarta: Mitra Pustaka Munawwaroh, Latifah. 2017. Penggunaan Kaidah Fiqhiyyah "Al-Khuruj Min AlKhilaf Mustahab" Terkait Bab Ibadah dalam Kitab l'anat Al Thalibin. Jurnal Nuansa, (Online), Jilid 14 No. 1 , (https://ejournal.stainpamekasan.a c.id, diakses 19 Agustus 2017).

Razaq, Abu Hafs. 1998. Panduan lengkap Nikah (dari "A" sampai "Z"). Terjemahan oleh Ahmad Saikhu. 2006. Bogor. Pustaka Ibnu Katsir

Rofiq, Ahmad. 2012. Hukum Perdata Islam di Indonesia. Edisi Revisi. Jakarta: Rajawali Pers.

Sabiq, Sayyid. Tanpa Tahun. Fiqhus Sunnah Jilid 2. Terjemahan oleh Moh. Abidun. 2008. Jakarta: Pena Pundi Aksara

Santrock, J. W. Tanpa Tahun. Adolescence. Terjemahan oleh Shinto B. Adelar dan Sherly

Sari, Fitri. 2012. Kesiapan Menikah Pada Dewasa Muda dan Pengaruhnya terhadap Usia Menikah. Skripsi Tidak Diterbitkan. Bogor Ekologi Manusia Institut Pertanian Bogor

Sasmita, Elvin. 2012. Menikahlah, Karena Allah Selalu Punya Rencana yang Jauh Lebih Baik. Kuliah Online Parenting Nabawiyah, (Online), (http://www.parentingnabawiyah. com, diakses 7 September 2017).
Schoeni, Robert F. 1995. Marital Status and Earnings in developed Countries. J Popul Econ, 8:351-359

Septiana, Ema dan Muhammad Syafiq. 2013. Identitas Lajang (Single Identity) dan Stigma: Studi Fenomologi Perempuan Lajang Di Surabaya. Jurnal Psikologi Teori \& Terapan, 4 (1): $71-86$

Solimun. 2002. Multivariate Analysis: Structural Equation Modelling (SEM), Lisrel dan Amos. Malang: Penerbit Universitas Negeri Malang Sriwidadi, Teguh. 2011. Penggunaan Uji Mann-Whitney pada Analisis Pengaruh Pelatihan Wiraniaga dalam Penjualan Produk Baru. Binus Business Review, 2 (2): 751-762 Sugiyono. 2011. Metode Penelitian Kuantitatif, Kualitatif, dan R\&D. Bandung: Alfabeta

Syarifuddin, Amir. 2004. Hukum Perkawinan Islam Di Indonesia. Jakarta: Predana Media Group

Tanau, Felinsa Oktora. 2016. Perbedaan Tingkat Kecenderungan Perilaku Altruisme pada Dewasa Awal dan Dewasa Madya. Skripsi Tidak Diterbitkan. Yogyakarta Psikologi Universitas Sanata Dharma

Umam, Khairul. 2001. Ushul Fiqih. Bandung: Pustaka Setia

Undang-undang Nomor 1 Tahun 1974 Tentang Perkawinan

Undang-Undang Republik Indonesia Nomor 36 Tahun 2008 tentang Perubahan Keempat atas Undang- 
Prayogo, et al/Jurnal Ekonomi Syariah Teori dan Terapan Vol. 6 No. 3 Maret 2019: 41 1-427; PERBANDINGAN TINGKAT PENGHASILAN ANTARA LAKI-LAKI LAJANG DAN LAKI-LAKI MENIKAH PERSPEKTIF ISLAM (STUDI PADA PENDUDUK LAKI-LAKI INDONESIA BERDASARKAN DATA INDONESIAN FAMILY LIFE SURVEY TAHUN 2007 DAN 2014)

Undang Nomor 7 Tahun 1984

tentang Pajak Penghasilan.

Usamah, Abu Hafs. 2006. Panduan Lengkap Nikah. Terjemahan oleh Ahmad Saikhu. Cetakan Kelima. Bogor: Pustaka llmu

Zagorsky, Jay L. 2005. Marriage and divorce's impact on wealth. Journal of Sociology, 41 (4): 406-424 